\title{
A Comparison of Epidural Anesthesia without Motor Block Versus General Anesthesia for Percutaneous Nephrolithotomy
}

\author{
Perkütan Nefrolitotomide Motor Bloksuz Epidural Anestezi ile Genel Anestezinin \\ Karşılaştırılması
}

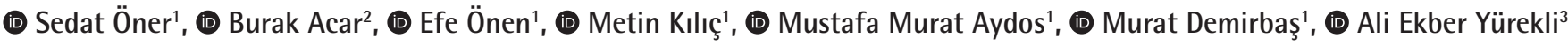 \\ 'University of Health Sciences, Bursa Yüksek Ihtisas Training and Research Hospital, Clinic of Urology, Bursa, Turkiye \\ ${ }^{2}$ Gemlik State Hospital, Clinic of Urology, Bursa, Turkiye \\ ${ }^{3}$ University of Health Sciences, Bursa Yüksek Ihtisas Training and Research Hospital, Clinic of Anesthesiology, Bursa, Turkiye
}

\section{What's known on the subject? and What does the study add?}

Today, epidural anesthesia in percutaneous nephrolithotomy operations is as effective as general anesthesia, safe and comfortable for the surgeon. This is why it is preferred in some clinics. We are on the lookout for its use even further, as it offers additional advantages such as less postoperative analgesic requirements and shorter operating times for the surgery room.

\begin{abstract}
Objective: The study carried out to compare the operative parameters and stone clearance in patients who underwent percutaneous nephrolithotomy (PNL) under epidural anesthesia (EA) without motor block versus those who underwent PNL under general anesthesia (GA).

Materials and Methods: We retrospectively reviewed 2 groups of patients who underwent PNL at our institute between January 2014 and September 2014. Group 1 consisted of 69 consecutive patients who underwent PNL under EA without motor block and group 2 consisted of 69 consecutive patients who underwent PNL under GA. Patients general characteristics, stone features, surgical parameters, duration of surgery, time spent in the operating room, postoperative analgesic requirements, complications, stone clearance rate and mean length of hospital stay were compared between the 2 groups.

Results: The two groups were similar in terms of mean age, gender, stone size and previous surgery. Operative time, access site, mean access number, postoperative fever, drainage, mean hemoglobin drop, stone-free rate, duration of nephrostomy tube and length of hospitalization were also similar between the groups. The time spent in the operating room, blood transfusion rate and postoperative analgesic requirements in EA group were significantly lower than those in GA group.

Conclusion: PNL under EA without motor block is as effective and safe as PNL under GA and it offers some advantages as with lower parenteral analgesic requirements, lower transfusion rates and lesser usage of operation room.
\end{abstract}

Keywords: Epidural, Anesthesia, Percutaneous nephrolithotomy

$\ddot{0} z$

Amaç: Çalışma, motor bloksuz epidural anestezi (EA) altında perkütan nefrolitotomi (PNL) uygulanan hastalara karşı genel anestezi (GA) uygulanan hastaların operasyon parametrelerini ve taş temizlenmesini karşılaştırmak için yürütülmüştür.

Gereç ve Yöntem: Ocak 2014 ile Eylül 2014 tarihleri arasında kliniğimizde PNL uygulanan iki grup geriye dönük olarak incelendi. Grup 1, motor bloksuz EA uygulanan ardışık 69 hasta ve grup 2 de GA altında PNL uygulanan ardışık 69 hastadan oluştu. İki grup arasında hastaların genel özellikleri, taş özellikleri, cerrahi parametreler, ameliyat süresi, ameliyat odasındaki süre, postoperatif analjezik gereksinimleri, komplikasyonlar, taş temizleme oranı ve ortalama hastanede kalış süreleri karşılaştırıldı.

Bulgular: İki grup arasında yaş, cinsiyet, taş boyutu ve daha önce yapılan cerrahi açısından benzerlik vardı. Her iki grupta da operasyon süresi, erişim yeri, ortalama erişim sayısı, ameliyat sonrası ateş, drenaj, ortalama hemoglobin düşmesi, taşsızlık oranı, nefrostomi süresi ve hastanede yatış süresi benzerdi. Ameliyat odasında geçen süre, kan transfüzyon oranı ve EA grubundaki postoperatif analjezik gereksinimleri GA grubundakilere göre anlamlı derecede düşüktü.

Correspondence: Efe Önen MD, University of Health Sciences, Bursa Yüksek İhtisas Training and Research Hospital, Clinic of Urology, Bursa, Turkiye Phone: +90 5063375824 E-mail: drefeonen@gmail.com ORCID-ID: orcid.org/0000-0001-9898-7808

Received: 02.01.2018 Accepted: 08.05.2018

Cite this article as: Öner S, Acar B, Önen E, Kılıç M, Aydos MM, Demirbaş M, Yürekli AE. A Comparison of Epidural Anesthesia without Motor Block Versus General Anesthesia for Percutaneous Nephrolithotomy. J Urol Surg 2018;5(3):143-148.

${ }^{\circ}$ Copyright 2018 by the Association of Urological Surgery / Journal of Urological Surgery published by Galenos Publishing House. 
Sonuç: Motor bloksuz EA ile yapılan PNL, GA altındaki PNL kadar etkili ve güvenlidir olup daha az parenteral analjezik gerekliliği, daha düşük transfüzyon oranları ve ameliyat odasının daha kısa süreli kullanımı gibi bazı avantajlar sunmaktadır.

Anahtar Kelimeler: Epidural, Anestezi, Perkütan nefrolitotomi

\section{Introduction}

Percutaneous nephrolithotomy (PNL) is the primary treatment modality for the management of most renal stones, especially for patients with large and multiple kidney stones $(>2 \mathrm{~cm})$, staghorn stones and cases of failed shock-wave lithotripsy $(1,2,3,4)$. PNL is generally carried out under general anesthesia $(\mathrm{GA})$ in the prone position $(1,5)$. However, $\mathrm{GA}$ is associated with higher rates of complication than regional anesthesia (RA) (6). Endotracheal tube migration and neurologic problems at the time of position transition may arise during PNL under GA (7). Furthermore GA has the risk of pulmonary complications; randomized controlled studies indicated that RA reduces postoperative mortality and other serious problems $(7,8,9)$. There have been a few studies conducted to compare PNL under RA and GA with respect to operative parameters $(10,11)$.

The present study was carried out as a prospective randomized study to compare surgical parameters, stone clearance, complication rates and postoperative pain between patients undergoing PNL under RA [epidural anesthesia (EA) without motor block] and those undergoing PNL under GA, and whether EA was a good alternative to GA in PNL.

\section{Materials and Methods}

Two groups of patients who underwent PNL between January 2014 and September 2014 at our institute were retrospectively reviewed. Group 1 consisted of 69 consecutive patients who underwent PNL under EA without motor block and group 2 consisted of 69 consecutive patients who underwent PNL under $\mathrm{GA}$. The type of anesthesia was decided by the anesthesiologist regardless of the comorbid conditions or the characteristics of the kidney stones. Patients under the age of 17 years and above the age of 80 years, with an American Society of Anesthesiologists (ASA) score above 3, with bilateral kidney stones, with solitary kidney, with radio-lucent stones and those requiring additional urological surgeries such as endopyelotomy and ureteroscopy were excluded. History taking, physical examination, preoperative laboratory tests (urinalysis, urine culture, complete blood count, renal function tests and liver function tests) and radiologic evaluation including kidneyureter-bladder (KUB) plain images, urinary ultrasound and/or intravenous urography and/or computed tomography (CT) were performed in all patients.

Patients with urine culture positive for microorganism were treated according to urine culture before the operation.
Calculated stone surface area was evaluated by multiplying the maximum diameter, width, $1 / 4 \pi$ of the stone seen on the plain radiography.

Chest X-ray and electrocardiogram were performed as a part of a fitness test for anesthesia and adequate blood was arranged. Written informed consent for the procedure both EA and GA was taken prior to the operation.

This retrospectively designed study was approved by Local Ethics Committee of University of Health Sciences Bursa Yüksek Intisas Training and Research Hospital (approval number: 2011-KAEK25 2016/09-07).

\section{Epidural Anesthesia without Motor Block}

Epidural catheter was introduced through an 18G needle in the intervertebral space at the T12-L1 level to produce sensorial anesthesia between T6 and S4 segments (from the kidney to the penile urethra) outside the operation room by an experienced anesthesiologist (A.Y.). A test dose (lidocaine $3 \mathrm{~mL}$ with adrenaline 1:200.000) was administrated. After that a 20

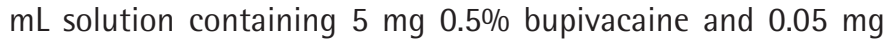
fentanyl per $\mathrm{mL}$ was injected through the epidural catheter and 15-20 minutes later, the patients were put into the operating room under sensorial anesthesia. Maintenance of anesthesia was supplied by the injection of the same solution in the amount of $10 \mathrm{~mL}$ per 90 minutes. By the administration of the drug in this concentration, only sensorial anesthesia was established (without motor block). Sedation of patients was done by intravenous administration of $50 \mu \mathrm{g}$ fentanyl or $0.01 \mathrm{mg} / \mathrm{kg}$ diazepam, if necessary. Postoperative pain control was provided by injection of $15-20 \mathrm{~mL}$ solution containing $3 \mathrm{mg} \mathrm{0.05 \%}$ bupivacaine and $0.05 \mathrm{mg}$ fentanyl in each milliliter, through the epidural catheter when needed (minimum 120 minutes interval) in group 1. Postoperative pain control in group 2 was provided by the intramuscular injection of diclofenac sodium (150 mg/ day) or meperidine $(200 \mathrm{mg} /$ day) until the patients could take the diclofenac sodium per orally.

\section{Percutaneous Nephrolithotomy Technique}

Standard PNL operation was done in both groups by an experienced urologist (S.0.). Cystoscopy and 6F ureteral catheterization were performed in the lithotomy position, after which the patients were shifted to the prone position. Puncture of the appropriate calyx was performed by an $18 \mathrm{G}$ needle under biplanar fluoroscopy guidance after imaging of the renal collecting system by the contrast material injection through the ureteral catheter. Sequential amplatz dilation of 
the tract over a 0.038 guidewire was performed and finally a $30 \mathrm{~F}$ working sheath was kept in the collecting system and a $26 \mathrm{~F}$ nephroscope was inserted. Normal saline was used for irrigation. The stones were fragmented with pneumatic lithotripter and the fragments were extracted with forceps. Stone clearance was assessed by the fluoroscopic control and a $16 \mathrm{~F}$ reentry nephrostomy catheter was placed at the end of the operation. The nephrostomy catheter was removed after 24-72 hours depending on the clearance of hematuria.

Duration of $E A$, mean time elapsed between entrance to operating room to cystoscopy start time, mean time from entrance to operating room to the beginning of the PNL operation, in-room time and duration of operation were recorded. Operation time was calculated as the time elapsed (in minutes) from the puncture of pelvicalyceal system until the insertion of the nephrostomy tube.

PNL-associated complications, such as hemorrhage requiring transfusion, fever, prolonged urinary drainage, severe urosepsis, pleural injury, colon injury, and hemorrhage requiring arterial embolization, perirenal hematoma, and death were classified according to the modified Clavien classification. Also complications, such as pain, hypotension, nausea and vomiting depending on the anesthesia, during the operation and postoperative period were recorded.

Our criteria for blood transfusion included a postoperative hemoglobin level of $<10 \mathrm{mg} / \mathrm{dL}$ with ongoing hematuria and/ or hemodynamic instability. In case of supracostal or upper calyceal puncture, chest $X$-ray was ordered to assess pleural injury. Stone clearance was evaluated by the KUB X-ray and/ or CT scan 3 weeks after surgery. Patients with no opacities on the X-ray and/or CT scan were considered stone free; those with opacities under $4 \mathrm{~mm}$ were considered to have clinically insignificant residual fragments.

\section{Statistical Analysis}

Statistical Package for the Social Sciences for Windows was used in the evaluation of the data of the study. Student's t-test, the Mann-Whitney U test and Pearson's coefficient were used for the evaluation of quantitative variables and $x^{2}$ test was used for the evaluation of the qualitative variables. A $p$ value of less than 0.05 was considered statistically significant.

\section{Results}

The patient and stone characteristics are shown in Table 1. The two groups were similar in age, sex, body mass index, ASA scores, location of stones, involvement of renal units, existence of hydronephrosis, and history of previous kidney operation.

There was no complication associated with epidural catheter placement procedure in group 1. All patients in group 1 passed to prone position themselves because of EA without motor block, the others passed that position with the help of operating room staff.

Two female patients (7.4\%) and 8 male patients (19.0\%), who received EA, complained of slight pain during cystoscopy when the cystoscope passing the bladder neck. Operation continued after additional injection of analgesics through the epidural catheter in these patients. Nausea-vomiting and hypotension

Table 1. Patient and stone characteristics

\begin{tabular}{llll}
\hline Characteristic & Group 1 (EA) $(\mathbf{n}=\mathbf{6 9})$ & Group 2 (GA) $(\mathbf{n}=\mathbf{6 9})$ & Significance \\
\hline Mean age (years) & $46.0(19-79)$ & $43.9(17-77)$ & 0.36 \\
Male/female & $42 / 27$ & $37 / 32$ & 0.51 \\
Mean BMI $\left(\mathrm{kg} / \mathrm{m}^{2}\right)$ & $28.6 \pm 6.3(19-47.2)$ & $28.3 \pm 5.9(18-46.8)$ & 0.44 \\
Mean ASA score & 1.3 & 1.2 & 0.18 \\
Site of stone & & & 0.45 \\
Single calyx & 13 & 12 & \\
Pelvic & 19 & 17 & \\
Pelvic + single calyx & 11 & 12 & \\
Multible calyx & 20 & 25 & \\
Staghorn & 6 & 3 & 0.59 \\
Hydronephrosis & & & \\
Yes & 46 & 42 & \\
No & 23 & 27 & 0.38 \\
Stone area (mm²) & $760(64-2952)$ & $678(120-2162)$ & 0.35 \\
Right/left kidney & $35 / 34$ & $28 / 41$ & 0.42 \\
Previous stone surgery & $18(26.0 \%)$ & $15(21.7 \%)$ & \\
\hline EA:Epion
\end{tabular}

EA: Epidural anesthesia, GA: General anesthesia, BMI: Body mass index, ASA: American Society of Anesthesiologists 
associated with EA (Clavien 1) were seen in 3 patients (4.3\%) and 7 patients (10.1\%) in group 1, respectively.

Operative findings are shown in Table 2. There was no difference in operative time, number of access (single or multiple access), access site, mean access number, fluoroscopy time, postoperative creatinine change, postoperative fever (Clavien 1), prolonged drainage (exceeding 72 hours) requiring double-j catheter insertion (Clavien 3A), stone-free rate, duration of nephrostomy tube and length of hospitalization (Table 2). Although the mean hemoglobin drop was similar between the groups, hemorrhage requiring blood transfusion (Clavien 2) rate was significantly lower in group 1. Overall in-room time in group 1 patients was significantly lower than in group 2 patients (Table 2). Parenteral analgesic requirement was significantly higher in group 2 (Table 2). There were no parenteral analgesic requirements in group 1 patients.

No patient required second-look PNL in both groups.

\section{Discussion}

PNL is the first-line treatment choice for managing renal stone disease, although several new techniques, such as retrograde intrarenal surgery and modification of $\mathrm{PNL}$, have been introduced (11). PNL is mostly performed under GA, although it can be done also under RA $(6,10,12,13,14,15,16)$. However, patients undergoing GA are more likely to have severe morbidities, such as drug-induced anaphylaxis, complications associated with endotracheal tube during the change of the position from lithotomy to prone, and cardiovascular, pulmonary and neurologic complications, than those receiving RA (14). During supracostal or upper pole puncture, patients can follow verbal commands and control respiration more easily under RA. In addition, advantages of RA over GA have been demonstrated in many other operations $(17,18)$.

Mostly combined spino-EA (CSEA) is used as RA in PNL operations. Kuzgunbay et al. (6) compared the efficacy and safety in 37

Table 2. Operative parameters

\begin{tabular}{|c|c|c|c|}
\hline Characteristic & Group $1(E A)(n=69)$ & Group $2(\mathrm{GA})(\mathrm{n}=69)$ & Significance \\
\hline Mean operation time (min) & $58.7(6-135)$ & $60.8(10-132)$ & 0.69 \\
\hline Mean time for the administration of epidural anesthesia (min) & $5.3(3-12)$ & - & - \\
\hline Mean time from entrance to operation room to start of cystoscopy (min) & $13.5(5-44)$ & $21.6(10-40)$ & 0.00 \\
\hline $\begin{array}{l}\text { Mean time from entrance to operation room to the beginning of the PNL } \\
\text { operation (min) }\end{array}$ & $36.5(14-187)$ & $42.4(18-84)$ & 0.05 \\
\hline Mean duration in operation room (min) & $103.0(49-230)$ & $117.8(55-190)$ & 0.01 \\
\hline Number of access & & & 0.75 \\
\hline Single & 56 & 57 & \\
\hline Multiple & 13 & 12 & \\
\hline Access site & & & 0.45 \\
\hline Upper calyx & $11(13 \%)$ & $11(13 \%)$ & \\
\hline Middle calyx & $33(39 \%)$ & $38(45 \%)$ & \\
\hline Lower calyx & $40(48 \%)$ & $35(42 \%)$ & \\
\hline Mean access number & $1.2(1-3)$ & $1.2(1-5)$ & 0.95 \\
\hline Fluoroscopy time (min) & 2.5 & 2.4 & 0.91 \\
\hline Mean hemoglobin drop $(\mathrm{g} / \mathrm{dL})$ & $1.9 \pm 0.08$ & $2.1 \pm 0.26$ & 0.13 \\
\hline Serum creatinine $(\mathrm{mg} / \mathrm{dL})$ & & & 0.69 \\
\hline Preoperative & $1.15 \pm 0.57$ & $1.04 \pm 0.25$ & \\
\hline Postoperative & $1.13 \pm 0.51$ & $1.05 \pm 0.28$ & \\
\hline Blood transfusion & 6 patients $(8.6 \%)$ & 15 patients $(21.7 \%)$ & 0.03 \\
\hline Postoperative fever & 3 patients $(4.3 \%)$ & 2 patients $(2.8 \%)$ & 0.68 \\
\hline Prolonged drainage & 1 patient (1.4\%) & 1 patient (1.4\%) & 0.33 \\
\hline Stone free & 63 patients (91.3\%) & 64 patients $(92.7 \%)$ & 0.83 \\
\hline Mean duration of nephrostomy tube (days) & 2.2 & 2 & 0.23 \\
\hline Mean hospitalization time (days) & 3 & 3 & 0.81 \\
\hline Parenteral analgesic requirements & None & 1.9 times $(0-4)$ & 0.01 \\
\hline
\end{tabular}


patients who underwent PNL under CSEA and 45 patients under GA. They concluded that PNL under CSEA was effective and safe as PNL under GA. Karacalar et al. (19) reported the superior results of spinal combined epidural anesthesia (SCEA) compared to GA in some aspects such as patient satisfaction, less postoperative pain and shorter duration of postoperative analgesic medication use. They observed no difference in the incidence of vomiting, itching, hypotension and bradycardia between the groups but higher rate of nausea was found in GA group. In their prospective randomized study comparing PNL under GA and PNL under SCEA, Sing et al. (10) found that the mean analgesic requirement within 24 hours was lower and hospital stay was shorter in SCEA group. RA is equally effective and safe compared to GA.

Studies comparing PNL under RA with PNL under GA have compared mostly spinal anesthesia (SA) or SCEA with GA. There is limited number of studies comparing PNL under EA with PNL under any other type of anesthesia. In a study of 50 patients comparing PNL under EA with PNL under GA, Tangpaitoon et al. (14) reported that EA had some advantages over GA including less nausea/vomiting, less postoperative pain, less analgesic drug usage and more patient satisfaction. There was no difference in postoperative hemoglobin values, operation time, postoperative complication, success rate and hospital stay between patients receiving EA and GA. However, the authors did not state if motor block was provided or not.

There are also a small number of studies comparing PNL under EA with PNL under the other RA techniques. Nandanwar et al. (20) compared PNL under EA and PNL under SA and they reported that segmental epidural block was better than SA in terms of hemodynamic stability, postoperative analgesia, patient satisfaction and reduced incidence of nausea and vomiting. They also stated that EA was difficult to execute and took longer time to act as compared to spinal block which limits its use (20).

In our study, epidural catheter was placed outside the operating room and the patients got into the operating room under sensorial anesthesia for using time efficiently. The duration of surgery was similar between the 2 groups. There was no recovery time in EA unlike $\mathrm{GA}$. With these advantages, the time spent in the operating room in EA group was significantly lower than that in GA group (Table 2). Since effective use of time in operating room is important, especially in clinics with excess surgical workload, EA can be superior to GA in this regard.

GA is prone to complicate in terms of vascular, pulmonary and neurological issues, especially during changing patient's position from lithotomy to prone (21). In our EA technique, we used a low concentration of local anesthetics with opioids and obtained sensorial and sympathetic block without any motor block. Thus, all the patients in EA group got the prone position themselves and were protected from the risk of complications during the position change under GA.

Some patients (2 women and 8 men) complained of slight pain during the passage of cystoscope through the bladder neck which is innervated more caudally. As known, epidural space widens caudally and the nerves are thicker and obtaining sensorial block is harder at that level. The efficiency of EA in that level also depends on the diffusion time of the anesthetic agent. The pain in these patients was probably due to the fact that the anesthetic agent did not reach to sacral segments or delayed. In these circumstances, operation can be continued by additional drug administration through epidural catheter or intravenous sedation with the mixture of fentanyl and diazepam.

To create percutaneous renal access and to continue PNL operation under EA are not different from that under $G A$, at least in our clinic. We did not experience any problem during the access formation under EA even in the upper pole, except in one patient. Thus, the number of upper pole access in EA group was similar to that in GA group (Table 2). PNL operation was continued after additional drug administration in that patient.

Another advantage of EA over GA is that you can cooperate with the patient during the surgery. Respiratory maneuvers necessary for avoiding pleural injury could be done more rapidly and easily.

Hypotension can be observed in PNL under EA because of sympathetic blockage. Nausea and vomiting are usually caused by hypotension. We observed hypotension and nausea-vomiting in $10.1 \%$ and $4.3 \%$ of patients, respectively. In these situations, sympathomimetics, antiemetics and volume expanders were used for treatment. Preoperative adequate hydration is more important in this aspect.

Although the mean hemoglobin drop was similar between the groups, the patients in EA group required significantly fewer blood transfusions (Table 2). Our criteria for blood transfusion were not only hemoglobin drop but also ongoing hematuria and/or hemodynamic instability. Although we could not show the main reason in the content of the literature, the significant difference in blood transfusion rates between the groups may be due to blood transfusion in patients with ongoing hematuria and/or hemodynamic instability.

Patient controlled analgesia through the epidural catheter provides postoperative pain control very well and minimize pulmonary and thromboembolic complications associated with postoperative pain-related mobilization restriction. It also protects patients from unnecessary analgesic injections and its possible complications, such as abscess, cellulitis and phlebitis. Thus, patients in EA group were not exposed to any parenteral analgesic injection, while patients in GA group were exposed to significantly more parenteral injection in our study (Table 2). 
EA did not prolong operative time and did not reduce success rate in PNL. It did not shorten length of hospitalization, but kept the patients more comfortably in that period.

\section{Study Limitations}

The limitations of this study are lack of perioperative and postoperative blood pressure variegation measurements and visual analog scale scores and its retrospective nature.

Our study is perhaps the first study in the literature which compares the surgical parameters, stone clearance and postoperative analgesic requirements following PNL under EA without motor block and under GA. However, further prospective randomised controlled studies are needed.

\section{Conclusion}

PNL under EA without motor block is equally effective and safe compared to PNL under GA. The advantages of EA over GA are less usage of operating room, self-positioning of patients from the lithotomy to the prone position, less early postoperative pain and less parenteral analgesic use without changing operative parameters and success rate.

\section{Ethics}

Ethics Committee Approval: This retrospectively designed study was approved by Local Ethics Committee of University of Health Sciences Bursa Yüksek İhtisas Training and Research Hospital (approval number: 2011-KAEK-25 2016/09-07).

Informed Consent: Because of its retrospective nature, no written informed consent was obtained from the patients.

Peer-review: Externally peer-reviewed.

\section{Authorship Contributions}

Surgical and Medical Practices: S.Ö., B.A., M.K., Concept: S.Ö., B.A., Design: S.Ö., B.A., Data Collection or Processing: S.Ö., E.Ö., A.E.Y., Analysis or Interpretation: B.A., Literature Search: M.M.A., M.D., Writing: S.Ö., E.Ö., B.A.

Conflict of Interest: No conflict of interest was declared by the authors.

Financial Disclosure: The authors declared that this study received no financial support.

\section{References}

1. Fernström I, Johansson B. Percutaneous pyelolithotomy: a new extraction technique. Scand J Urol Nephrol 1976;10:257-259.

2. Preminger GM, Assimos DG, Lingeman JE, Nakada SY, Pearle MS, Wolf JS Jr; AUA Nephrolithiasis Guideline Panel). Chapter 1: AUA guideline on management of staghorn calculi: diagnosis and treatment recommendations. J Urol 2005;173:1991-2000.
3. Stening SG, Bourne S. Supracostal percutaneous nephrolithotomy for upper pole caliceal calculi. J Endourol 1998;12:359-362.

4. Kim SC, Kuo RL, Lingeman JE. Percutaneous nephrolithotomy: an update. Curr Opin Urol 2003;13:235-241.

5. El Husseiny T, Moraitis K, Maan Z, Papatsoris A, Saunders P, Golden B, Masood J, Buchholz NP. Percutaneous endourologic procedures in high risk patients in the lateral decubitis position under regional anesthesia. J Endourol 2009;23:1603-1606.

6. Kuzgunbay B, Turunc $T$, Akin $S$, Ergenoglu $P$, Aribogan A, Ozkardes $H$. Percutaneous nephrolithotomy under general versus combined spinalepidural anesthesia. J Endourol 2009;23:1835-1838.

7. Ferreyra G, Long $Y$, Ranieri VM. Respiratory complications after major surgery. Current Opin Crit Care 2009;15:342-348.

8. Malbouisson LM, Humberto F, Rodrigues Rdos R, Carmona MJ, Auler JO. Atelectasis during anesthesia: pathophysiology and treatment. Rev Bras Anestesiol 2008;58:73-83.

9. Rodgers A, Walker N, Schug $S$, McKee A, Kehlet $H$, van Zundert A, Sage D, Futter M, Saville G, Clark T, MacMahon S. Reduction of postoperative mortality and morbidity with epidural or spinal anesthesia: results from overview of randomized trials. BMJ 2000;321:1493-1505.

10. Sing V, Sinha RJ, Sankhwar SN, Malik A. A prospective randomized study comparing percutaneous nephrolithotomy under combined spinal-epidural anesthesia with percutaneous nephrolithotomy under general anesthesia. Urol Int 2011;87:293-298.

11. Tiselius HG, Ackermann D, Alken $\mathrm{P}$, Buck $\mathrm{C}$, Conort $\mathrm{P}$, Gallucci $\mathrm{M}$; Working Party on Lithiasis, European Association of Urology. Guidelines on urolithiasis. Eur Urol 2001;40:362-371.

12. Moslemi MK, Mousavi-Bahar SH, Abedinzadeh M. The feasibility of regional anesthesia in the percutaneous nephrolithotomy with supracostal approach and its comparison with general anesthesia. Urolithiasis 2013;41:53-57.

13. Gonen M, Basaran B. Tubeless pecutaneous nephrolithotomy: spinal versus general anesthesia. Urol J 2014;11:1211-1215.

14. Tangpaitoon T, Nisoog C, Lojanapiwat B. Efficacy and safety of percutaneous nephrolithotomy: A prospective and randomized study comparing regional epidural anesthesia with general anesthesia. Int Braz J Urol 2012;38:504511.

15. Dalela D, Goel A, Singh P, Shankwar SN. Renal capsular block: a novel method for performing percutaneous nephrolithotomy under local anesthesia. J Endourol 2004;18:544-546.

16. Park HK, Paick SH, Oh SJ, Kim HH. Ureteroscopic lithotripsy under local anesthesia: analysis of effectiveness and patient tolerability. Eur Urol 2004; 45:670-673.

17. Salonia A, Suardi N, Crescenti A, Colombo R, Rigatti P, Montorsi F. General versus spinal anesthesia with different forms of sedation in patients undergoing radical retropubic prostatectomy: results of prospective, randomized study. Int J Urol 2006;13:1185-1190.

18. Maurer SG, Chen Al, Hiebert R, Pereira GC, Di Cesare PE. Comparison of outcomes of using spinal versus general anesthesia in total hip arthroplasty. Am J Orthop (Belle Mead NJ) 2007;36:101-106.

19. Karacalar S, Bilen CY, Sarihasan B, Sarikaya S. Spinal-epidural anesthesia versus general anesthesia in the management of percutaneous nephrolithotomy. J Endourol 2009;23:1591-1597.

20. Nandanwar AS, Patil Y, Wagaskar VG, Baheti VH, Tanwar HV, Patwardhan SK. A comparison of efficacy of segmental epidural block versus spinal anaesthesia for percutaneous nephrolithotomy. J Clin Diag Res 2015;9:1-4.

21. Mehrabi S, Karimzadeh Shirazi K. Results and complications of spinal anesthesia in percutaneous nephrolithotomy. Urol J 2010;7:756-761. 